\title{
Macro- and micro-geographic variation of short-beaked common dolphin's whistles in the Mediterranean Sea and Atlantic Ocean
}

\author{
E. Papale ${ }^{1,9}$, M. Azzolin ${ }^{1}$, I. Cascão ${ }^{2}$, A. Gannier ${ }^{3}$, M.O. Lammers ${ }^{4,5}$, \\ V.M. Martin ${ }^{6}$, J. Oswald ${ }^{7}$, M. Perez-GIL ${ }^{6}$, R. Prieto ${ }^{2}$, M.A. Silva ${ }^{2,8}$ \\ and C. GIACOMA ${ }^{1}$
}

${ }^{1}$ Life Sciences and Systems Biology Department, University of Torino, Via Accademia Albertina 13, 10123 Torino, Italy

${ }^{2}$ Departamento de Oceanografia e Pescas, IMAR and LARSyS Associated Laboratory, Universidade dos Açores, 9901-862 Horta, Portugal

${ }^{3}$ Groupe de Recherche sur les Cétacés (GREC), Antibes, France

${ }^{4}$ Ocean wide Science Institute, PO Box 61692, Honolulu, HI 96744, USA

${ }^{5}$ Hawaii Institute of Marine Biology, University of Hawaii, Kaneohe, HI 96744, USA

${ }^{6}$ Society for the Study of Cetaceans in the Canary Archipelago (SECAC), Edif. Antiguo Varadero $1^{a}$ planta Local 8 B, Urb. Puerto Calero, 35571 Yaiza, Isla de Lanzarote, Spain ${ }^{7}$ Bio-Waves Inc., 144 W. D Street, Suite \#205, Encinitas, CA 92024, USA

${ }^{8}$ Biology Department, Woods Hole Oceanographic Institution, MS\#33, Woods Hole, MA 02543, USA

Received 17 October 2012, accepted 26 September 2013

Genetic studies have shown that there are small but significant differences between the short-beaked common dolphin populations in the Atlantic Ocean and those in the Mediterranean Sea. The short-beaked common dolphin is a highly vocal species with a wide sound production repertoire including whistles. Whistles are continuous, narrowband, frequency-modulated signals that can show geographic variation in dolphin species. This study tests whether the differences, highlighted by genetic studies, are recognisable in the acoustic features of short-beaked common dolphin's whistles in the two adjacent areas of the Atlantic Ocean and the Mediterranean Sea. From a selected sample of good quality whistles (514 recorded in the Atlantic and 193 in the Mediterranean) 10 parameters of duration, frequency and frequency modulation were measured. Comparing data among basins, differences were found for duration and all frequency parameters except for minimum frequency. Modulation parameters showed the highest coefficient of variation. Through discriminant analysis we correctly assigned $75.7 \%$ of sounds to their basins. Furthermore, micro-geographic analysis revealed similarity between the sounds recorded around the Azores and the Canary archipelagos and between the Bay of Biscay and the Mediterranean Sea. Results are in agreement with the hypothesis proposed by previous genetic studies that two distinct populations are present, still

9 Corresponding author: Elena Papale, Università di Torino, Via Accademia Albertina 13, 10123

Torino, Italy (E-mail: elena.papale@unito.it or elenabiancapapale@gmail.com). 
supposing a gene flow between the basins. This study is the first to compare shortbeaked common dolphin's whistles of the Atlantic Ocean and the Mediterranean areas.

KEY WORDS: short-beaked common dolphin, intra-specific differences, geographic variation, Mediterranean, Atlantic, whistles.

\section{INTRODUCTION}

Animal vocalisations are characterized by features under different selective forces and each trait may vary independently (GERHARDT 1991). Delphinids exhibit a high level of plasticity in the production of their communication signals (MAY-COLLADO 2010). Whistles are continuous, narrowband, frequency-modulated signals that often have harmonic components (OSWALD et al. 2008) and are believed to have a social function (JANIK \& SLATER 1998; HERzING 2000; LAMmERS et al. 2003). Geographic variation in delphinid signal characteristics can be caused by genetic, environmental or cultural differences (JANIK \& SLATER 2000). Morphology and physiology (particularly the energetic and nutritional state of animals) can also affect sound production (JANIK 2009). Finally, ambient noise level also plays a role in the whistle structure of dolphins (Morisaka et al. 2005b; May-Collado \& WartzoK 2008). Man-made noise has been suggested as the explanation for acoustic differences described both in the frequency and modulation of short-beaked common dolphins' (Delphinus delphis) whistles between the English Channel and the Celtic Sea (ANSMAnn 2005; ANSMAnN et al. 2007). Intra-specific variation in this type of vocalization has been assessed both at macro- (differences that occur over long distances and between populations that are geographically separated (KREBS \& KROODSMA 1980)) and micro-geographic scales (variation between contiguous groups; KREBS \& KROODSMA 1980), especially for Tursiops spp. (WANG et al. 1995; Jones \& SAYIGH 2002; CAMPBEll 2004; MoRISAKA et al. 2005a, 2005b; BARON et al. 2008; MAY-Collado \& WARTZOK 2008; HaWKins 2010; May-Collado 2010), Stenella frontalis (BARON et al. 2008), Pseudorca crassidens, Grampus griseus, Globicephala macrorhynchus and Globicephala melas (RENDELL et al. 1999), Sotalia guianensis (Azevedo \& VAN Sluys 2005; Rossi-Santos \& Podos 2006), Stenella longirostris (BAzÚA-DuRÁN \& AU 2004; CAMARgo et al. 2006) and Stenella coeruleoalba (Azzolin et al. 2013; PAPALE et al. 2013).

Intra-specific variation in whistles among delphinids occurs mainly in signal duration and in the number of contour inflection points (MORISAKA et al. 2005a; RossISANTOS \& PoDOS 2006) and is thought to carry information about individual identity or contextual behaviour (BAZÚA-DURÁN \& AU 2004). Still, differences within the species are known to occur also in other parameters, including beginning and maximum frequency (Rossi-SANTOS \& Podos 2006; BARON et al. 2008). In some geographic areas, a gradual, continuous divergent tendency emerges (WANG et al. 1995; AzzoLIN et al. 2013) while at other locations discontinuities exist along an apparent continuum in the geographic distribution of dolphins (Rossi-SANTOS \& Podos 2006).

Since communication is useful for cohesion, cooperation and the survival of a social group, differences in acoustic production of a species can indicate the presence of populations or groups using specific communication signals (WANG et al. 1995; DatTa \& STURTIVANT 2002). Differences in acoustic characteristics can be a sign of isolation and can be used to distinguish conservation units in a refined way (HAWKINS 
2010). For short-beaked common dolphins this hypothesis was proposed by GRIFFITHS (2009), analysing whistle samples in Celtic Deep and Eastern Tropical Pacific Ocean and by Azzolin (2008) in the Mediterranean Sea.

The short-beaked common dolphin is a highly vocal species with a wide repertoire composed of echolocation clicks (peak frequency between 23 and $67 \mathrm{kHz}$ ), "chirps" (between 8 and $14 \mathrm{kHz}$ ), "barks" (below $3 \mathrm{kHz}$ ) and whistles (generally between 2 and $18 \mathrm{kHz}$ ) (CALDWELl \& CALDWELl 1968; AU 1993; RICHARDSON et al. 1995). The species has to cope with a number of threats arising from human-induced impacts (ForcADA \& HAMMOND 1998; TUdELA et al. 2005; BEARZI et al. 2010) including habitat deterioration, bioaccumulation of pollutants (BORRELL et al. 2001; ZHOU et al. 2001) and the effects of climate change (BRERETON et al. 2010). This situation is more evident in the Mediterranean Sea, where the subpopulation was recently listed as endangered under the 2003 International Union for Conservation of Nature (IUCN) Red List of Threatened Species (BEARZI 2003), as demographic studies demonstrated a strong decline in the population, particularly in the eastern basin (BEARZI et al. 2008). The most important remaining habitat for the Mediterranean subpopulation is located in the Alboran Sea, in the western basin (CANÃDAS \& HAMmOND 2008). The Alboran Sea population is differentiated from the Atlantic populations at the level of the mitochondrial DNA (mtDNA) but results suggest that there is a gene flow out of the Strait of Gibraltar (NATOLI et al. 2008). On the other hand, a homogeneous distribution of gene frequencies in Northeast and Mid-Atlantic short-beaked common dolphins suggests that these are part of a large, distinct population (VIRICEL 2006; MIRIMIN et al. 2009; QUÉROUIL et al. 2010). This results from the high dispersal capability of the species across oceans (EVANs 1982; DANIL \& CHIVERS 2006).

The aim of this study was to investigate geographic variation in the characteristics of whistle sounds of short-beaked common dolphins living in the Atlantic Ocean and the Mediterranean Sea in order to identify different groups or populations of dolphins. The main objective was to evaluate if the whistle acoustic structure, which is thought to differ between the Atlantic Ocean and Mediterranean Sea, can be considered as an indicator of at least two evolutionary units. We also assessed which parameters contributed most to the discrimination and evaluated possible acoustic contact between populations.

\section{METHODS}

\section{Study populations and data collection}

Recordings from two macro-geographic areas were used: the Atlantic Ocean (around the Azores and the Canary Islands, and in the Bay of Biscay) and the Mediterranean Sea (Western basin: from the Alboran to the Tyrrhenian Seas) (Fig. 1).

We used only recordings in which the species was visually identified with certainty and short-beaked common dolphins were the only species present in the area. Five research groups contributed data for the study: SECAC (Society for the Study of Cetaceans in the Canary Archipelago-Spain) collected data in the Canary archipelago and utilized a towed array with four elements: two Benthos hydrophones (with a linear flat response of $\pm 1 \mathrm{~dB}$ between $1 \mathrm{~Hz}$ and $15 \mathrm{kHz}$, and of $\pm 3 \mathrm{~dB}$ between $15 \mathrm{kHz}$ and $30 \mathrm{kHz}$ ) and two spherical ceramic hydrophone elements with a frequency response of $\sim 2-150 \mathrm{kHz}$ (Seiche UK Ltd). Signals were immediately visualized and collected on a laptop using the acoustic monitoring software package PAMGuard. Sounds were digitalized at a sampling rate of $192 \mathrm{kHz}$. 


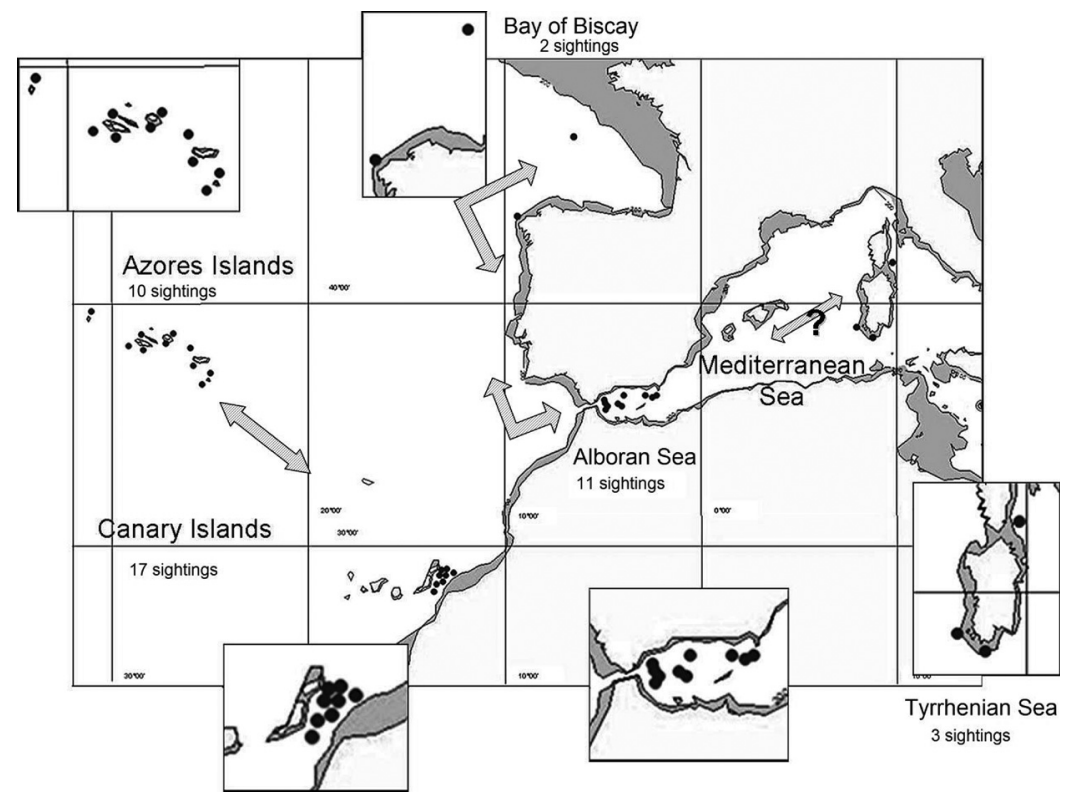

Fig. 1. - Recording locations (black dots) of common dolphins' whistles used in the study. Details of the three Atlantic sites and two Mediterranean sites are shown as insets. Shading, $200 \mathrm{~m}$ contour. Arrows represent genetic flows hypothesized for the species in the study area by NATOLI et al. (2008); MiRIMIN et al. (2009) and QuerouIL et al. (2010).

IMAR-DOP/UAç (Institute of Marine Research, Department of Oceanography and Fisheries, Centre of IMAR of the University of the Azores-Portugal) provided data from the Azores recorded with either an omnidirectional hydrophone (HTI-94-SSQ with a flat response of $\pm 2 \mathrm{~dB}$ from $2 \mathrm{~Hz}$ to $30 \mathrm{kHz}$ ) or a towed array with two hydrophones (Benthos ; recordings were made with a digital tape recorder Tascam ${ }^{\circledR} \mathrm{DA}-\mathrm{P} 1$, with a sampling frequency of $48 \mathrm{kHz}, 16$-bit resolution and frequency responses from $20 \mathrm{~Hz}$ to $20 \mathrm{kHz} \pm 0.5 \mathrm{~dB}$ ). Signals were digitalized at a sampling rate of $48 \mathrm{kHz}$.

IFAW (International Fund for Animal Welfare-United Kingdom) collected data from the Bay of Biscay and the Mediterranean basin using the same instruments and sampling rate as IMAR-DOP/UAç.

GREC (Research Group about Cetaceans-France) collected data in the Mediterranean Area, using a mono towed hydrophone with Benthos in 1999 and a stereo towed with the same hydrophone elements during the other years with a flat response of $\pm 2 \mathrm{~dB}$ from $200 \mathrm{~Hz}$ to $30 \mathrm{kHz}$, a $29 \mathrm{~dB}$ pre-amplifier and $200 \mathrm{~Hz}$ high-pass filter. An external high-pass filter unit (Magrec Ltd) set to $1 \mathrm{kHz}$ was used on the hydrophone output to improve the quality of recording. The sampling rate used in this case was $32 \mathrm{kHz}, 44.1 \mathrm{kHz}$ and $48 \mathrm{kHz}$.

ALNITAK (Marine Environment Research and Education Centre, Spain) provided data from the Alboran basin in the Mediterranean Sea and recorded with an omnidirectional hydrophone with a flat response of $\pm 2 \mathrm{~dB}$ from $200 \mathrm{~Hz}$ to $30 \mathrm{kHz}$ as GREC but with a sampling rate of $48 \mathrm{kHz}$.

All recordings were made from vessels. Table 1 details the data collection periods and instruments used by the five research groups.

\section{Data analysis}

Sound recordings were analyzed by creating spectrograms in CoolEdit 2000 (Syntrillium Software, USA) (Blackmann-Harris window; 256-512 band resolution; 2048 FFT (Fast Fourier 


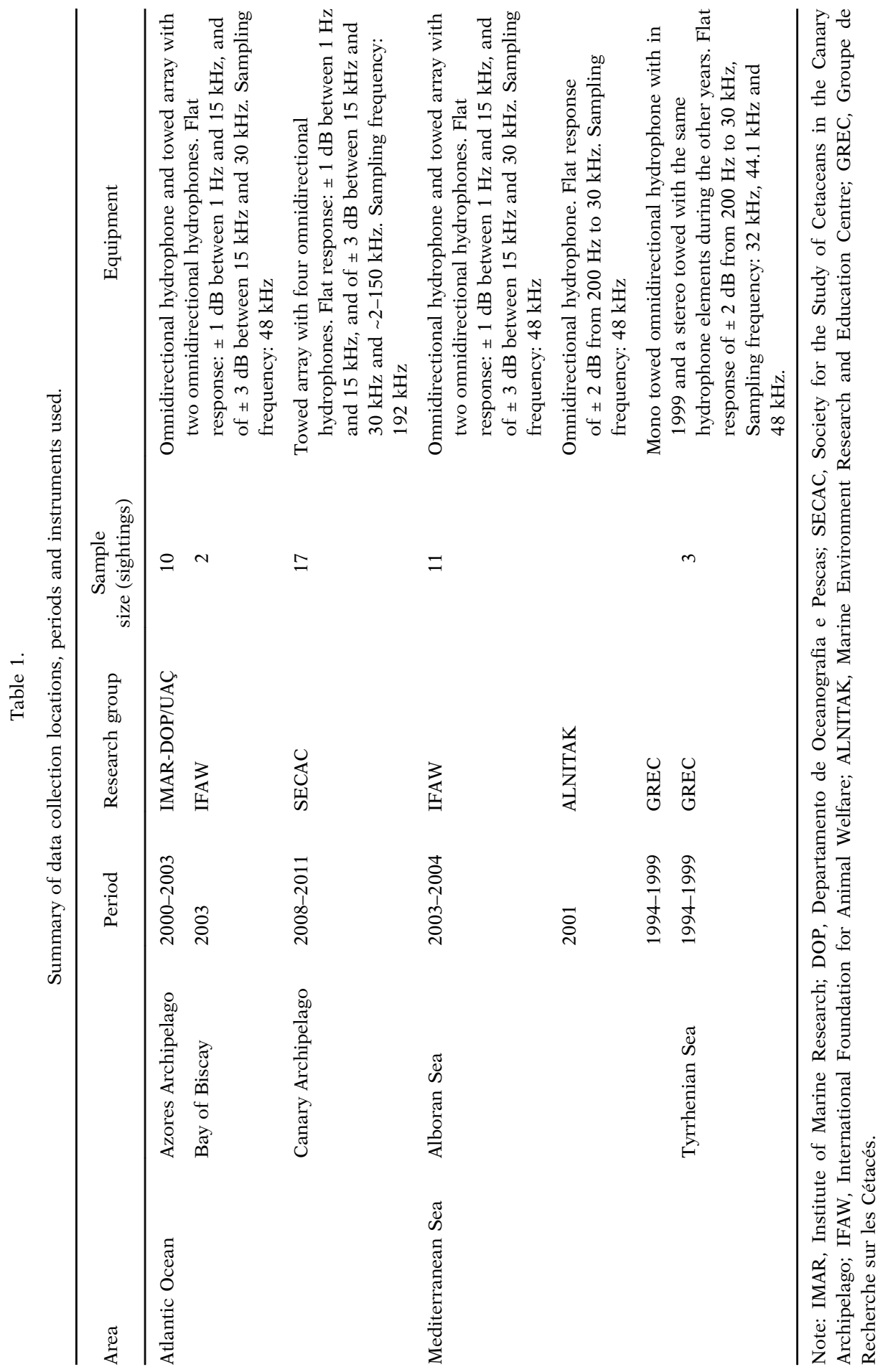


Transform) size). From each whistle contour, the following 10 parameters were measured manually (after OswALD et al. 2003, 2007; Azzolin 2008): duration, beginning frequency, end frequency, minimum frequency, maximum frequency, number of inflection points (mathematic definition in sine function of a change from positive to negative or negative to positive slope), steps (a discontinuous change in frequency), number of minima in the contour and number of maxima in the contour (Fig. 2). We calculated also the frequency range (as maximum frequency - minimum frequency). In order to avoid sources of bias in the manual analysis measurements we verified the agreement among two observers on a subsample of the dataset and compared results from the manual analysis with the ones obtained in a semi-automated way using the methodology validated by Azzolin (2008). There were no significant differences between the semi-automated method and the human observer (Wilkoxon test on a sub-sample: $n=191,-1.7<\mathrm{Z}<-0.49,0.08<P<0.62$ ).

Each sound was also classified by assigning a signal quality index from 0 (weak or overlapped with other sounds) to 3 (good intensity and definition of the contour). All whistles classified as 2 (when the complete contour could be recognised but intensity was low) and 3 (when intensity was high and time-frequency contour well defined) as specified in PAPALE et al. (2013) were considered high quality and used for statistical analysis.

We used $6.59 \mathrm{hr}$ of recordings from the Atlantic area obtained during 29 sightings (two from the Bay of Biscay, 17 from the Canaries and 10 from the Azores) between 2000 and 2011. A total of 1061 whistles were extracted from the recordings but only 514 high-quality signals were analyzed (30 from the Bay of Biscay, 293 from the Canaries and 191 from the Azores). We used $8.30 \mathrm{hr}$ of recordings from the Mediterranean area obtained during 14 sightings (11 from the Alboran and three from the Tyrrhenian Seas collected between 1994 and 2004). A total of 249 whistles were extracted and 193 were analyzed (137 from the Alboran Sea and 56 from the Tyrrhenian). The mean group size for the

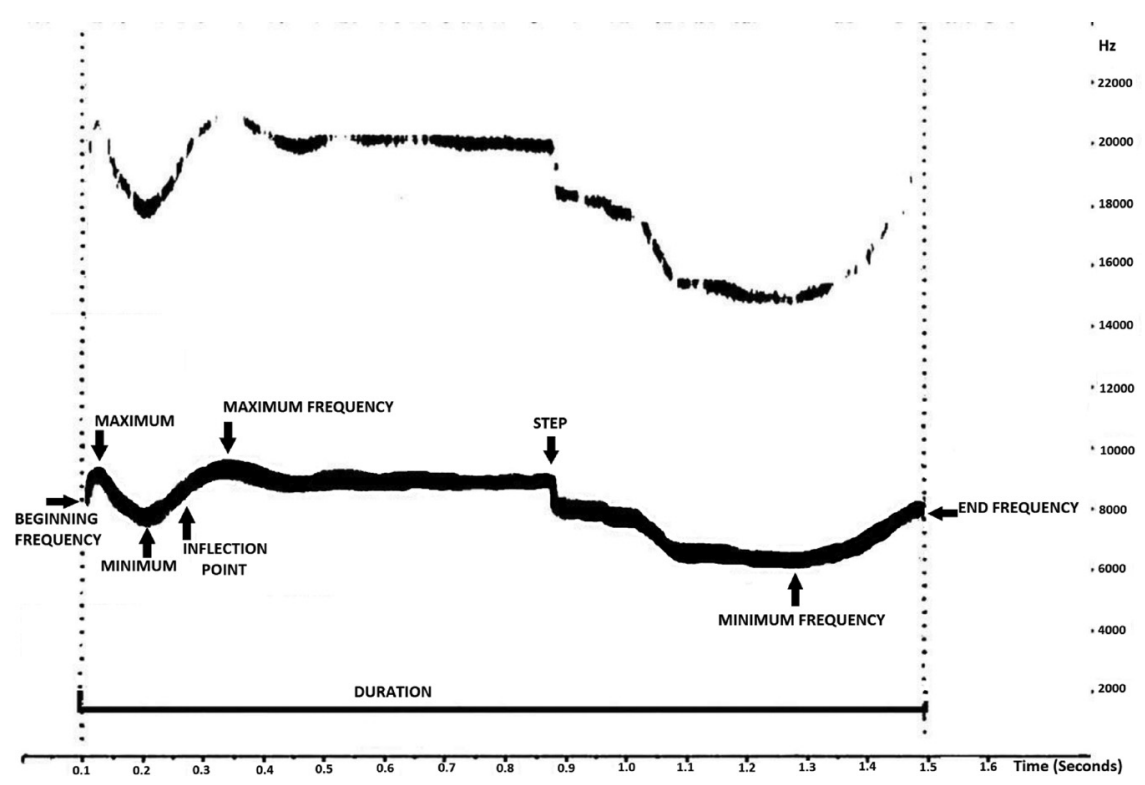

Fig. 2. - Spectrogram of a whistle call (Blackmann-Harris window; 256-512 band resolution; 2048 FFT size) showing the variables measured in the study (except frequency range): duration, beginning frequency, end frequency, minimum frequency, maximum frequency, number of inflection points (mathematic definition in sine function of a change from positive to negative or negative to positive slope), steps (a discontinuous change in frequency), number of minima in the contour and number of maxima in the contour (one maximum and one minimum are shown in the figure; these were counted to provide two variables - see Methods). 
Atlantic sightings was 35 ( $\mathrm{SD}=36.14)$, while for the Mediterranean was $11(\mathrm{SD}=7.77)$. All sightings consisted of more than one individual. Since we could not know the emitter we considered a mean of three sounds per animal per sighting. Furthermore, in order to avoid autocorrelation effects due to the presence of sounds with similar time-frequency contours (emitted from the same animal or a mimicry by a conspecific), sounds with similar contours could not make up more than $10 \%$ of total sounds in the whole dataset. Only 4\% of sounds in the dataset were composed of broken whistles which can arise when vocalizing animals are not facing towards the recording source.

The statistical software PASW Statistics 18.0 (SPSS Institute Inc., Chicago, Illinois, USA) was used to create descriptive statistics (mean, standard deviation). For each parameter considered, within- and between-basin coefficients of variation were calculated (SoKAL \& ROHLF 1995). Comparative statistical analyses of whistle parameters between populations were made using the nonparametric Mann-Whitney test (since data were not normally distributed) to determine whether parameters varied between populations, while the Kolmogorov-Smirnov test was used to investigate within-population variability.

We performed a discriminant function analysis (DFA) to evaluate if recorded whistles could be correctly classified according to the sampling areas using all parameters except the frequency range because of its direct dependence from maximum and minimum frequencies. The leave-one-out procedure (LACHENBRUCH \& Mickey 1968) was then used for cross-validation.

We then used the mean values for each sighting in order to assess the similarity between areas reducing the weight of each single sound (since there were only two sightings in the Bay of Biscay). In this case, we repeated the DFA on 10 randomly selected sub-samples, composed of $80 \%$ of the complete sighting set.

\section{RESULTS}

We calculated the intra-basin coefficient of variation ( $\mathrm{CV}$ ) for every parameter. Atlantic and Mediterranean short-beaked common dolphins displayed a low CV for all frequency parameters and duration (from 19 to 50\%), especially for minimum and maximum frequencies, and a higher variability for modulation parameters (CV over $80 \%$ ).

Within each area, duration and frequency parameters did not show significant variation, except for beginning (Kolmogorov-Smirnov test $n=514, Z=1.99, P=0.001$ ) and end frequencies (Kolmogorov-Smirnov test $n=514, Z=1.94, P=0.001$ ) in the Atlantic Ocean. On the other hand, the number of steps and inflection points exhibited significant variation within both basins (Kolmogorov-Smirnov Test, Atlantic: $n=514$, $Z=6.00, P<0.001 ; Z=5.53, P<0.001$; Mediterranean: $n=193, Z=4.15, P<0.001$; $Z=2.46, P<0.001)$.

Table 2 summarizes mean values and standard deviations of whistle parameters for the two basins. Significant differences between the Atlantic and the Mediterranean were found in whistle duration (Mann-Whitney test $n=707, P=0.017$ ), and all frequency parameters (Mann-Whitney test $n=707$ : beginning frequency $P<0.001$; end frequency $P=0.001$; maximum frequency $P=0.001$; frequency range $P<0.001$ ) with the exception of minimum frequency $(P=0.973)$. Since minimum frequency was higher and maximum frequency was significantly lower in the Mediterranean Sea, the frequency range was significantly narrower than in the Atlantic Ocean.

The mean number of inflection points was significantly lower in the Atlantic (Mann-Whitney Test $n=707, P<0.001$ ) while the number of steps was higher but not significantly different from the Mediterranean.

With respect to the other contour parameters, the number of minima was significantly lower in the Atlantic (Mann-Whitney Test $n=707, P=0.001$ ) and the number of maxima was similar between the two areas. 
Table 2 .

Mean (and standard deviation) and CV of 10 parameters of whistle calls recorded in the Mediterranean and the Atlantic. $P$ value (Mann Whitney $U$ test) refers to the comparison between Mediterranean and Atlantic.

\begin{tabular}{lrrrrr}
\hline Parameters & $\begin{array}{c}\text { Atlantic } \\
\text { Ocean } \\
(n=514)\end{array}$ & \multicolumn{1}{c}{ CV } & $\begin{array}{c}\text { Mediterranean } \\
\text { Sea }(n=193)\end{array}$ & CV & $P$ value \\
\hline Beginning frequency kHz & $13.02(4.98)$ & 38.24 & $11.08(4.25)$ & 38.34 & $<0.001$ \\
Frequency range kHz & $8.60(3.43)$ & 39.92 & $7.48(3.09)$ & 41.29 & $<0.001$ \\
Inflection points & $1.06(1.24)$ & 116.97 & $2.05(1.65)$ & 80.76 & $<0.001$ \\
Maximum frequency kHz & $16.74(3.55)$ & 21.23 & $15.67(3.04)$ & 19.38 & 0.001 \\
End frequency kHz & $11.77(3.98)$ & 33.84 & $12.62(3.48)$ & 27.62 & 0.001 \\
No. of minima & $0.77(0.83)$ & 108.32 & $1.02(1.16)$ & 113.62 & 0.001 \\
Duration & $0.95(0.38)$ & 40.00 & $0.85(0.43)$ & 50.94 & 0.017 \\
Steps & $1.82(2.90)$ & 159.24 & $1.54(2.92)$ & 189.39 & 0.086 \\
No. of maxima & $0.65(0.83)$ & 127.72 & $0.59(1.11)$ & 187.04 & 0.100 \\
Minimum frequency kHz & $8.14(1.77)$ & 21.73 & $8.19(2.31)$ & 28.21 & 0.973 \\
\hline
\end{tabular}

$\mathrm{CV}$, coefficient of variation.

We also performed a stepwise DFA between the Atlantic Ocean and the Mediterranean Sea using whistle duration, all the frequency parameters except frequency range and the modulation parameters as predictor variables. Overall, the function correctly classified $75.7 \%$ of cases: $76.8 \%$ for the Atlantic and $72.5 \%$ for the Mediterranean. DFA showed that the number of inflection points, steps, minima and the minimum frequency contributed to the discrimination (coefficients: number of inflection points $=1.14$, number of steps $=0.35$, number of minima $=0.28$, minimum frequency $=0.27$.

The DFA correctly discriminated 51.2\% of the whistles from the Azores, Canaries, Bay of Biscay and Mediterranean areas. For signals coming from the Azores and Canary archipelagos the correct assignments were almost 50\%, while the misclassification to the other archipelago was of $20-25 \%$ (Table 3). Only the parameters of number of minima and maxima were significantly different $(\mathrm{N}=484, Z=-6.16, P<0.001$; $Z=-5.73, P<0.001)$ between the two archipelagos.

The DFA also assigned 70\% of the sounds from the Bay of Biscay to either the Bay of Biscay or the Mediterranean Sea. In the DFAs performed after the randomization test, $100 \%$ of the cases belonging to the Bay of Biscay were distributed between this site and the Mediterranean Sea, while almost $80 \%$ of the whistles from the Mediterranean Sea were assigned to the two areas.

\section{DISCUSSION}

Geographic variation in the acoustic features of a species' signals can be a clue to help identify distinct populations (HAWKINS 2010). Understanding the acoustic 
Table of assignments of the discriminant function analysis (DFA) performed among the areas (overall correct classification $51.2 \%)$.

\begin{tabular}{|c|c|c|c|c|c|}
\hline \multirow[b]{2}{*}{ Area } & & \multicolumn{4}{|c|}{ Predicted group membership } \\
\hline & & $\begin{array}{l}\text { Canary } \\
\text { Islands }\end{array}$ & $\begin{array}{l}\text { Azores } \\
\text { Islands }\end{array}$ & $\begin{array}{l}\text { Bay of } \\
\text { Biscay }\end{array}$ & $\begin{array}{l}\text { Mediterranean } \\
\text { Sea }\end{array}$ \\
\hline \multirow{8}{*}{$\begin{array}{l}\text { Cross- } \\
\text { validated }\end{array}$} & Canary Islands $(n=293)$ & 145 & 73 & 31 & 44 \\
\hline & Azores Islands $(n=191)$ & 40 & 89 & 25 & 37 \\
\hline & Bay of Biscay $(n=30)$ & 3 & 5 & 15 & 7 \\
\hline & $\begin{array}{l}\text { Mediterranean Sea } \\
\quad(n=193)\end{array}$ & 35 & 23 & 22 & 113 \\
\hline & Canary Islands & $49.5 \%$ & $24.9 \%$ & $10.6 \%$ & $15.0 \%$ \\
\hline & Azores Islands & $20.9 \%$ & $46.6 \%$ & $13.1 \%$ & $19.4 \%$ \\
\hline & Bay of Biscay & $10.0 \%$ & $16.7 \%$ & $\mathbf{5 0 . 0} \%$ & $23.3 \%$ \\
\hline & Mediterranean Sea & $18.1 \%$ & $11.9 \%$ & $11.4 \%$ & $58.5 \%$ \\
\hline
\end{tabular}

Note: The correct classification score for each area appears in bold.

differences can assist in identifying isolation mechanisms of cetacean populations, evaluating their conservation status, recognizing endangered units and monitoring population changes.

The results show that signal frequency and duration parameters exhibited a low CV whereas modulation parameters showed a high CV. Values with the lowest CV in this case are also the most influenced by morphological and genetic aspects, in agreement with Mousseau \& RofF (1987). Frequency parameters usually present high variation between species and low variation within species (STEINER 1981; RENDELL et al. 1999) representing reliable indicators of species identity, while modulation parameters (number of steps and inflection points) exhibit high intra-specific coefficients of variation (RENDELL et al. 1999; Oswald et al. 2003). According to MAY-Collado \& WARTZOK (2008), a high whistle complexity (measured in terms of mean number of inflection points) and a high intra-specific variability can result from the transmission of emotional states and individual differences. As suggested by Popov \& SHUVALOV (1977) "essential recognition parameters" are normally the most stable characteristics of the acoustic signal, whereas "motivational parameters" are often highly variable. In our case, the results of little or no difference in minimum frequency reported in this study are in agreement with the hypothesis of MAY-Collado et al. (2007) that this parameter appears to be strictly influenced by body size and the most relevant marker of species identity. The same result was recently found in a similar species (Stenella coeruleoalba) for the same area (PAPALE et al. 2013).

The results obtained for all the parameter categories (duration, frequency and frequency modulation) indicate that individuals from the Mediterranean are differentiated from the population inhabiting the Northeastern and Mid-Atlantic areas. Mean values of maximum frequency and frequency range were lower in the Mediterranean, 
whereas end frequency was lower in the Atlantic. Also, mean whistle duration was significantly shorter in the Mediterranean Sea. The distinction is further supported by the DFA results, which correctly classified $76.8 \%$ and $72.5 \%$ of Atlantic and Mediterranean whistles, respectively. We can exclude any bias due to the equipment or the sampling frequency in these results because no off-scale signals were used and whistles with the highest sampling frequency have been visualized at the standard frequency of $48 \mathrm{kHz}$.

These findings can be the sign of either (1) genotypic influences on the acoustic features through phenotypic differentiation of isolated groups, or (2) parallel but independent variation of acoustic and genotypic features due to geographic isolation. Similar results were found for striped dolphins (Azzolin et al. 2013; PAPALE et al. 2013). Even if the subjacent cause cannot be addressed with the present data, the results demonstrate some degree of isolation between the Mediterranean Sea and Atlantic Ocean populations, in agreement with prior genetic studies (NATOLI et al. 2008).

Looking into a micro-geographic scale, genetic studies suggest a possible gene flow within oceanic areas (QUÉRouIL et al. 2010) and from the Mediterranean along the eastern coast of the Atlantic Ocean (NATOLI et al. 2008). A recent study (QUÉROUIL et al. 2013) reveals faint stock differences among oceanic dolphins using fatty acid and stable isotope analyses. Our results show little variation between the Azores and Canary archipelagos and between the Bay of Biscay and the Mediterranean Sea. The acoustic parameters have usually been considered more similar due to the possibility of intermixing (HAWKINS \& GARTSIDE 2008) and the dispersal of offspring (CONNOR et al. 2000) across neighbouring groups. It is likely that the acoustic similarities have a relation with the ranging behaviour of dolphins from oceanic areas and coastal habitats.

Acoustic studies regarding vocal variation in communication signals could have a considerable feedback on conservation. The conservation aspects of a possible contact between the populations of the Bay of Biscay and the Mediterranean Sea are especially relevant for this last population that is considered isolated and at risk due to anthropogenic impacts (BEARZI 2003), although inside the Mediterranean there is probably a potential for local specialization that requires further investigation.

The results reported here reveal that the whistles of Atlantic and Mediterranean short-beaked common dolphins are an indicator of their population of origin. Acoustic features, therefore, represent evidence to be considered concerning conservation issues for this species.

\section{ACKNOWLEDGEMENTS}

The authors are grateful to ALNITAK and IFAW (International Foundation for Animal Welfare) research groups for their contribution in data collection. Without their support this project could not have been realized. Data collection and processing in the Azores was conducted under projects POCTI/BSE/38991/01, PTDC/MAR/74071/2006 and M2.1.2/F/012/2011, supported by FCT (Fundação para a Ciência e a Tecnologia) and DRCTC/SRCTE (Secretaria Regional de Ciência, Tecnologia e Equipamentos), FEDER funds, the Competitiveness Factors Operational (COMPETE), QREN European Social Fund and Proconvergencia Açores Program. We acknowledge funds provided by FCT to LARSyS Associated Laboratory \& IMAR-University of the Azores/ the Thematic Area E of the Strategic Project (OE \& Compete) and by the DRCTC - Government of the Azores pluriannual funding. M.A. Silva was supported by an FCT postdoctoral grant (SFRH/ BPD/29841/2006). I. Cascão and R. Prieto were supported by FCT doctoral grants (SFRH/BD/ $41192 / 2007$ and SFRH/BD/32520/2006, respectively) and R. Prieto by a research grant from the 
Azores Regional Fund for Science and Technology (M3.1.5/F/115/2012). Data collection by SECAC (Society for the Study of Cetaceans in the Canary Archipelago) was funded by the U.E. LIFE programme - project LIFE INDEMARES (LIFE 07/NAT/E/000732)- and the Fundación

Biodiversidad, under the Spanish Ministry of Environment, Rural and Marine Affairs (project ZEC-TURSIOPS). Many thanks also to Alice Galli for the GIS representation and to Marco Gamba and Peter Tyack whose comments improved the paper.

\section{REFERENCES}

Ansmann I.C. 2005. The whistle repertoire and acoustic behaviour of short-beaked common dolphins, Delphinus delphis, around the British Isles, with applications for acoustic surveying. Ph.D. Thesis, University of Wales, Bangor.

Ansmann I.C., Goold J.C., Evans P.G.H., Simmonds M. \& Keith S.G. 2007. Variation in the whistle characteristics of short-beaked common dolphins, Delphinus delphis, at two locations around the British Isles. Journal of the Marine Biological Association of the United Kingdom 87: 19-26.

Au W.W.L. 1993. The sonar of dolphins. New York, NY: Springer-Verlag.

Azevedo A.F. \& VAN Sluys M. 2005. Whistles of tucuxi dolphins (Sotalia fluviatilis) in Brazil: comparisons among populations. Journal of the Acoustic Society of America 117: 1456-1464.

Azzolin M. 2008. Identificazione acustica degli odontoceti del Mediterraneo come prerequisito per il monitoraggio acustico passivo. Ph.D. Thesis, University of Torino, Italy.

Azzolin M., Papale E., Lammers M.O., Gannier A. \& Giacoma C. 2013. Geographic variation of whistles of the striped dolphin (Stenella coeruleoalba) within the Mediterranean Sea. Journal of the Acoustical Society of America 134: 694-705.

Baron S.C., Martinez A., Garrison L.P. \& Keith E.O. 2008. Differences in acoustic signals from delphinids in the western North Atlantic and northern Gulf of Mexico. Marine Mammal Science 24: 42-56.

Bazua-Duran C. \& Au W.W.L. 2004. Geographic variations in the whistles of spinner dolphins (Stenella longirostris) of the Main Hawaiian Islands. Journal of the Acoustic Society of America 116: 3757-3769.

BeArzi G. 2003. Delphinus delphis (Mediterranean subpopulation). In: IUCN Red List of Threatened Species (Version 2011.2. www.iucnredlist.org).

Bearzi G., Agazzi S., Gonzalvo J., Bonizzoni S., Costa M. \& Petroselli A. 2010. Biomass removal by dolphins and fisheries in a Mediterranean Sea coastal area: do dolphins have an ecological impact on fisheries?. Aquatic Conservation: Marine and Freshwater Ecosystems (DOI: 10.1002/aqc.1123).

Bearzi G., Agazzi S., Gonzalvo J., Costa M., Bonizzoni S., Politi E., Piroddi C. \& Reeves R.R. 2008. Overfishing and the disappearance of short-beaked common dolphins from western Greece. Endangered Species Research 5: 1-12.

Borrell A., Cantos G., Pastor T. \& Aguilar A. 2001. Organochlorine compound in common dolphins (Delphinus delphis) from the Atlantic and Mediterranean waters of Spain. Environmental Pollution 114: 265-274.

Brereton T., Macleod C.D., Robinson K., Lambert E., Bannon S.M., Hall K. \& Costa M. 2010. Water temperature and distribution of the common dolphin (Delphinus delphis) in British shelf waters: a potential indicator of climate change impacts. Abstract of the 24th Conference of the European Cetacean Society, Stralsund, Germany.

Caldwell M.C. \& Caldwell D.K. 1968. Vocalization of naïve captive dolphins in small groups. Science 159: 1121-1123.

Camargo F.S., Rollo M.M., Giampaoli V. \& Bellini C. 2006. Whistle variability in South Atlantic spinner dolphins from the Fernando de Noronha Archipelago off Brazil. Journal of the Acoustic Society of America 120: 4071-4079.

Campbell G.S. 2004. Quantitative comparison of bottlenose dolphin (Tursiops spp.) whistles from three geographic regions. Thesis Presented to the Faculty of San Diego State University, USA. 
Cañadas A. \& Hammond P.S. 2008. Abundance and habitat preferences of the short-beaked common dolphin Delphinus delphis in the southwestern Mediterranean: implications for conservation. Endangered Species Research 4: 309-331.

Connor R.C., Wells R.S., Mann J. \& Read A.J. 2000. The bottlenose dolphin-social relationships in a fission-fusion society, pp. 91-126. In: Mann J. et al., Eds. Cetacean societies-field studies of dolphins and whales. Chicago: The University of Chicago Press.

DANIL K. \& Chivers S.J. 2006. Habitat-based spatial and temporal variability in life history characteristics of female common dolphins Delphinus delphis in the eastern tropical Pacific. Marine Ecology Progress Series 318: 277-286.

Datta S. \& Sturtivant C. 2002. Dolphin whistle classification for determining group identities. Signal Process 82: 251-258.

Evans W.E. 1982. Distribution and differentiation of stocks of Delphinus delphis Linnaeus in the northeastern Pacific. FAO Fisheries Series No. 5, Volume IV. 45-66 in Mammals in the seas. Rome: Food and Agriculture Organisations of the United Nations.

ForCADA J. \& HAMmond P.S. 1998. Geographical variation in abundance of striped and common dolphins of the western Mediterranean. Journal of Sea Research 39: 313-325.

Gerhardt H.C. 1991. Female choice in treefrogs: static and dynamic acoustic criteria. Animal Behaviour 42: 615-635.

GRIFFITHS E.T. 2009. Whistle repertoire analysis of the short-beaked common dolphin, Delphinus delphis, from the Celtic Deep and the Eastern Tropical Pacific Ocean. Thesis of the Master of Science, Marine Biology School of Ocean Sciences Bangor University, UK.

Hawkins E.R. 2010. Geographic variations in the whistles of bottlenose dolphins (Tursiops aduncus) along the east and west coasts of Australia. Journal of Acoustic Society of America 128: 924-935.

Hawkins E.R. \& GaRTSIDE D.F. 2008. Social and behavioural characteristics of Indopacific bottlenose dolphins (Tursiops aduncus) in northern New South Wales, Australia. Australian Mammalogy 30: 71-82.

Herzing D.L. 2000. Acoustics and social behaviour of wild dolphins: Implications for a sound society, pp. 225-272. In: Au W.W.L. et al., Eds. Hearing by whales and dolphins. New York, NY: Springer-Verlag.

JANIK V.M. 2009. Acoustic communication in delphinids, pp. 123-157. In: Naguib M. et al., Eds. Advances in the study of behaviour. Vol 40. Vocal communication in birds and mammals. New York, NY: Academic Press.

JANIK V.M. \& Slater P.J.B. 1998. Context-specific use suggests that bottlenose dolphin signature whistles are cohesion calls. Animal Behaviour 56: 829-838.

Janik V.M. \& Slater P.J.B. 2000. The different roles of social learning in vocal communication. Animal Behaviour 60: 1-11.

Jones G.J. \& SAYIGH L.S. 2002. Geographic variation in rates of vocal production of free ranging bottlenose dolphins. Marine Mammal Science 18: 374-393.

Krebs J.R. \& Kroodsma D.E. 1980. Repertoires and geographical variation in bird song. Advances in the Study of Behaviour 11: 143-177.

Lachenbruch P.A. \& Mickey M.R. 1968. Estimation of error rates in discriminant analysis. Technometrics 10: 1-11.

Lammers M.O., Au W.W.L. \& Herzing D.L. 2003. The broadband social acoustic signaling behavior of spinner and spotted dolphins. Journal of Acoustic Society of America 114: 1629-1639.

May-Collado L.J. 2010. Changes in whistle structure of two dolphin species during interspecific associations. Ethology 116: 1-10.

May-Collado L.J., Agnarsson I. \& Wartzok D. 2007. Reexamining the relationship between body size and tonal signal frequency in whales: a comparative phylogenetic approach. Marine Mammal Science 23: 524-552.

May-Collado L.J. \& Wartzok D. 2008. A comparison of bottlenose dolphin whistles in the Atlantic Ocean: factors promoting whistle variation. Journal of Mammalogy 89: 1229-1240.

Mirimin L., Westgate A., Rogan E., Rosel P., Read A., Coughlan J. \& Cross T. 2009. Population structure of short-beaked common dolphins (Delphinus delphis) in the North Atlantic Ocean as revealed by mitochondrial and nuclear genetic markers. Marine Biology 156: 821-834. 
Morisaka T., Shinohara M., Nakahara F. \& Akamatsu T. 2005a. Geographic variations in the whistles among three Indo-Pacific bottlenose dolphin Tursiops aduncus populations in Japan. Fishery Science 71: 568-576.

Morisaka T., Shinohara M., Nakahara F. \& Akamatsu T. 2005b. Effects of ambient noise on the whistles of Indo-Pacific bottlenose dolphin populations. Journal of Mammalogy 86: 541-546.

Mousseau T.A. \& Roff D.A. 1987. Natural selection and the heritability of fitness components. Heredity 59: 181-197.

Natoli A., Canãdas A., Vaquero C., Politi E., Fernandez-Navarro P. \& Hoelzel A.R. 2008. Conservation genetics of the short-beaked common dolphin (Delphinus delphis) in the Mediterranean Sea and in the eastern North Atlantic Ocean. Conservation Genetics 9: 1479-1487.

Oswald J.N., Barlow J. \& Norris T.F. 2003. Acoustic identification of nine delphinid species in the eastern tropical Pacific Ocean. Marine Mammal Science 19: 20-37.

Oswald J.N., Rankin S. \& Barlow J. 2008. To whistle or not to whistle? Geographic variation in the whistling behaviour of small odontocetes. Aquatic Mammals 34: 288-302.

Oswald J.N., Rankin S., Barlow J. \& Lammers M.O. 2007. A tool for real-time acoustic species identification of delphinid whistles. Journal of Acoustic Society of America 122: 587-595.

Papale E., Azzolin M., Cascão I., Gannier A., Lammers M.O., Martin V.M., Oswald J., PerezGil M., Prieto R., Silva M.A. \& Giacoma C. 2013. Geographic variability in the acoustic parameters of striped dolphin's (Stenella coeruleoalba) whistles. Journal of Acoustic Society of America 133: 1126-1134.

Popov A.V. \& Shuvalov V.F. 1977. Phonotactic behaviour of crickets. Journal of Comparative Physiology 119: 111-126.

Quérouil S., Freitas L., Cascão I., Alves F., Dinis A., Almeida J.R., Prieto R., Borràs S., Matos J.A., Mendonça D. \& Santos R.S. 2010. Molecular insight into the population structure of common and spotted dolphins inhabiting the pelagic waters of the Northeast Atlantic. Marine Biology 157: 2567-2580.

Quérouil S., Kiszka J., Cordeiro A.R., Cascão I., Freitas L., Dinis A., Alves F., Santos R.S. \& BANDARRA N.M. 2013. Investigating stock structure and trophic relationships among islandassociated dolphins in the oceanic waters of the North Atlantic using fatty acid and stable isotope analyses. Marine Biology (DOI 10.1007/s00227-013-2184-x).

Rendell L.E., Matthews J.N., Gill A., Gordon J.C.D. \& Macdonald D.W. 1999. Quantitative analysis of tonal calls from five odontocete species, examining interspecific and intraspecific variation. Journal of Zoology 249: 403-410.

Richardson W.J., Greene C.R. Jr, Malme C.I. \& Thomson D.H. 1995. Marine mammals and noise. San Diego, CA: Academic Press.

Rossi-Santos M.R. \& Podos J. 2006. Latitudinal variation in whistle structure of the estuarine dolphin Sotalia guianensis. Behaviour 143: 347-364.

SoKal R.R. \& RohlF F.J. 1995. Biometry: the principles and practice of statistics in biological research (3rd ed.). New York, NY: W.H. Freeman and Co.

STEINER W.W. 1981. Species-specific differences in pure tonal whistle vocalizations of five western north Atlantic dolphin species. Behavioral Ecology and Sociobiology 9: 241-246.

Tudela S., Kai Kai A., Maynou F., El Andalossi M. \& Guglielmi P. 2005. Driftnet fishing and biodiversity conservation: the case study of the large-scale Moroccan driftnet fleet operating in the Alboran Sea (SW Mediterranean). Biological Conservation 121: 65-78.

VIRICEL A. 2006. Spatial and social structure of the common dolphin Delphinus delphis in the Northeast Atlantic inferred from genetic data. MSc Thesis, The Graduate School of the College of Charleston, USA.

WANG D., Würsig B. \& Evans W. 1995. Comparisons of whistles among seven odontocete species, pp. 299-323. In: Kastelein R.A. et al., Eds. Sensory systems of aquatic mammals. Woerden: De Spil.

Zhou J.L., Salvador S.M., Liu Y.P. \& Sequeira M. 2001. Heavy metals in the tissues of common dolphins Delphinus delphis stranded on the Portuguese coast. Science of the Total. Environment 273: 61-76. 